\title{
Direct Metallization Using Surface Modification of Thermosetting Polyphenylene Ether Resin Laminate
}

\author{
Hidemi NAWAFUNE*, Toshinobu KANAI*, Kohei KUGO*, \\ Shozo MIZUMOTO*, Masaru SEITA** and Keiji ARAI**
}

熱硬化型 PPE樹脂の表面改質を利用するダイレクトプレーティング

\author{
縄舟秀美*，金井敏信 ${ }^{*}$, 久後行平 ${ }^{*}$, 水本省三* ${ }^{*}$ 清田 優**，新居啓二***
}

Key Words : Direct Metallization, PPE Resin Laminate, Surface Modification, Copper Ion Adsorption, Conductive Film

\section{Introduction}

The electronics industry is constantly researching organic materials with low dielectric constant and high glass transition temperature for printed wirering boards. Thermoplastic poly [2,6-dimethyl-1,4-phenylene ether ] (PPE ) was chemically modified into thermosetting allylated PPE without sacrificing superior properties, such as low dielectric constant, high glass transition temperature, and low water absorption ${ }^{1}$.

In this paper, a new method for formation of a copper thin film on a thermosetting allylated PPE (A-PPE) resin laminate through surface modification with chromic acid mixture of the laminate followed by adsorption and reduction of copper ions was investigated.

\section{Experimental}

The aromatic poly-phenylene ether (A-PPE) resin laminate (Asahi Chemical Industry Ltd.) was used ${ }^{1)}$. Test samples of the A-PPE resin laminate were dipped in $3 \mathrm{M} \mathrm{CrO}_{3} / 4 \mathrm{M} \mathrm{H}_{2} \mathrm{SO}_{4}$ mixture at $50^{\circ} \mathrm{C}$, thoroughly rinsed, and then dried.

Carboxylation of surface of the A-PPE laminate were confirmed by FTIR and XPS spectrometer. FTIR ATR spectra were obtained on a Nicolet Magna 750 FTIR spectrometer equipped with a Nic-Plan microscope (Spectra-Tech Inc.) using an ATR objective (zinc selenide). XPS spectra were obtained on an ULVAC-PHI ESCA system 5400 MC.

The carboxylated samples were dipped in $0.05 \mathrm{M}$

* Fac. of Sci., Konan Univ. (8-9-1 Okamoto, Higashinadaku, Kobe-shi, Hyogo 658, Japan)

甲南大学理学部

** LeaRonal Japan Inc. (2-269-4 Yoshinocho, Ohmiyashi, Saitama 330 , Japan)

日本リーロナール(怢)

*** Fujitsu Limited (64 Nishiwaki, Ohkubo-cho, Akashishi, Hyogo 674, Japan)

富士通侏)
$\mathrm{CuSO}_{4}$ solution for $5 \mathrm{~min}$ to adsorb the copper ions. After rinsing, the test samples adsorbed copper ions were dipped in $\mathrm{NaBH}_{4}$ solution for 5 min, producing a conductive through reduction of the copper ion to form a copper thin film. The surface conductivity of the test samples was measured using multimeter. The adsorbed copper ion was dissolved in $5 \% \mathrm{HNO}_{3}$ solution and measured by atomic absorption spectrometry.

\section{Results and discussion}

Fig. 1 shows the FTIR ATR spectra of A-PPE resin laminates untreated and treated with $3 \mathrm{M}$ $\mathrm{CrO}_{3} / 4 \mathrm{M} \mathrm{H}_{2} \mathrm{SO}_{4}$ at $50^{\circ} \mathrm{C}$. According to these spectra, skeletal structure of A-PPE resin appeared at $1602,1420,1376,1304$, and $1181 \mathrm{~cm}^{-1}$, respectively ${ }^{2)}$. The triallyl-1,3,5-triajino-2,4,6-trione for setting and cross-linking agent appeared at 1677, 1448, and $1303 \mathrm{~cm}^{-1}$, respectively ${ }^{3)}$. The intensity of the peak due to the skeletal structure

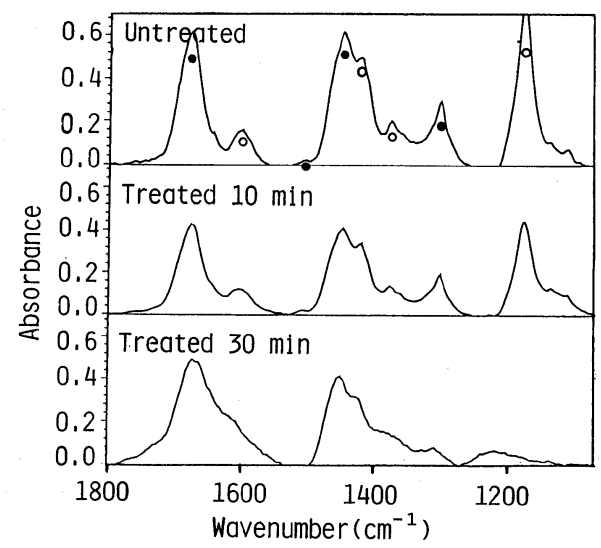

Fig. 1 FTIR ATR spectra of thermosetting PPE resin surface modified with $3 \mathrm{M} \mathrm{CrO}_{3} / 4 \mathrm{M} \mathrm{H}_{2} \mathrm{SO}_{4}$ at $50^{\circ} \mathrm{C}$.

Poly (2,6-dimethyl-1,4-phenylene ether)

- Triallyl-1,3,6-triajino-2,4,6-trione 

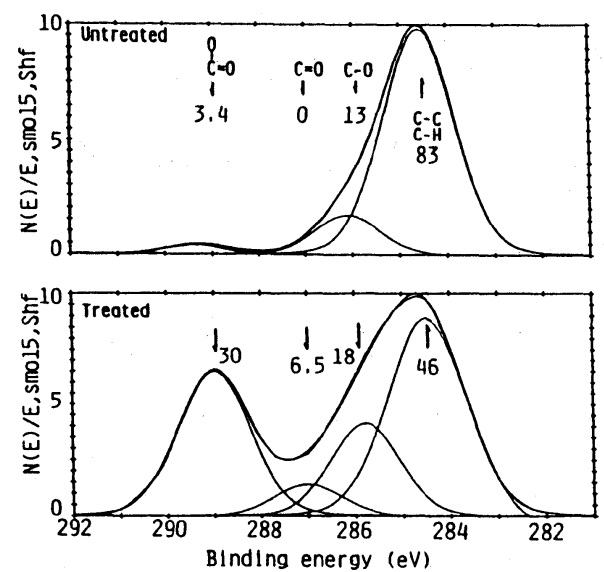

Fig. 2 XPS (C 1s) spectra of thermosetting PPE resin surface modified with $3 \mathrm{M} \mathrm{CrO}_{3} / 4 \mathrm{M} \mathrm{H}_{2} \mathrm{SO}_{4}$ at $50^{\circ} \mathrm{C}$ for $30 \mathrm{~min}$

Numerals : Peak area ratio (at.\%)

of A-PPE resin decreased with the $\mathrm{CrO}_{3} / \mathrm{H}_{2} \mathrm{SO}_{4}$ treatment, and new peaks assigned to carboxyl group appeared from 1700 to $1620 \mathrm{~cm}^{-1}$ regions.

Fig. 2 shows the C 1s XPS core level spectra for the A-PPE resin laminates treated with $3 \mathrm{M} \mathrm{CrO}_{3}$ $/ 4 \mathrm{M} \mathrm{H}_{2} \mathrm{SO}_{4}$ at $50^{\circ} \mathrm{C}$ for $30 \mathrm{~min}$. The $\mathrm{CrO}_{3} / \mathrm{H}_{2} \mathrm{SO}_{4}$ treatment makes the increase of the $\mathrm{C}-\mathrm{O}$ component, the $\mathrm{C}=\mathrm{O}$ component, and the $\mathrm{COO}$ component, and simultaneously makes the $\mathrm{C}-\mathrm{H}$ and /or C-C component decrease. The COO concentration increases from $3 \%$ to $30 \%$, and the $\mathrm{C}=\mathrm{O}$ from $0 \%$ to $7 \%$. A decrease of the $\mathrm{C}-\mathrm{H}$ and/or C-C component concentration increase from $83 \%$ to $46 \%$ means that there is degradation of aromatic rings in the A-PPE resin by the $\mathrm{CrO}_{3}$ $/ \mathrm{H}_{2} \mathrm{SO}_{4}$ treatment. From the $\mathrm{C} 1 \mathrm{~s}$ core level spectra, we conclude that the $\mathrm{CrO}_{3} / \mathrm{H}_{2} \mathrm{SO}_{4}$ treatment leads to the predominant formation of the $\mathrm{COO}$ component as an oxygen functionality, and also the degradaition of aromatic rings in the A-PPE resin laminates.

The A-PPE resin laminates were dipped in $3 \mathrm{M}$ $\mathrm{CrO}_{3} / 4 \mathrm{M} \mathrm{H}_{2} \mathrm{SO}_{4}$ solutions at $50^{\circ} \mathrm{C}$ for $30 \mathrm{~min}$, and then dipped in $0.05 \mathrm{M}$ copper sulfate solution for 3 min to adsorb the copper ions. After rinsing, the samples were treated with $5 \% \mathrm{HNO}_{3}$ solution to dissolve copper ions, and the concentration of copper ions was determined by atomic absorption spectrometry. The results are shown in Fig. 3. The amount of adsorbed copper ions increases as an exponential function with increasing $\mathrm{CrO}_{3}$ and $\mathrm{H}_{2} \mathrm{SO}_{4}$ concentration, and was 350 $\mathrm{nmol} / \mathrm{cm}^{2}$ on the sample treated with $3 \mathrm{M} \mathrm{CrO}_{3} /$ $4 \mathrm{M} \mathrm{H}_{2} \mathrm{SO}_{4}$ solution. Using the copper lattice constant, $0.362 \mathrm{~nm}$, the thickness of the copper

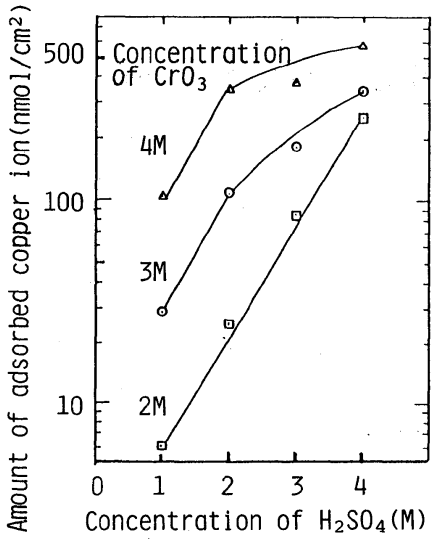

Fig. 3 Amount of adsorbed copper ions on thermosetting $\mathrm{PPE}$ resin surface modified with $\mathrm{CrO}_{3} / \mathrm{H}_{2} \mathrm{SO}_{4}$ at $50^{\circ} \mathrm{C}$ for $30 \mathrm{~min}$.

thin film formed after the reduction process was estimated to be $26 \mathrm{~nm}$.

The test samples adsorbed copper ions were reducted with $\mathrm{NaBH}_{4}$ solutions for $5 \mathrm{~min}$. The maximum value of the conductivity of the test samples was $6 \mathrm{nS} / \square$ at $0.004 \mathrm{M} \mathrm{NaBH}_{4}$, and the surface appeared to be bright metallic copper. However, the conductivity value obtained was inconsistent with the expected value from the adsorbed copper ions on the A-PPE resin surface $^{4)}$. Thus the discrepancy in the conductivity comes from surface cracks, which reaching glassfiber cloth of the laminate.

\section{Conclusion}

A new conducting method for an A-PPE resin laminate was proposed in this paper. The carboxy group, as a cation exchange group, was introduced onto the A-PPE resin laminate surface through the $\mathrm{CrO}_{3} / \mathrm{H}_{2} \mathrm{SO}_{4}$ treatment. The amount of adsorbed copper ions increased with increasing $\mathrm{CrO}_{3}$ and $\mathrm{H}_{2} \mathrm{SO}_{4}$ concentration, and was $350 \mathrm{nmol} / \mathrm{cm}^{2}$ on the sample treated with $3 \mathrm{M}$ $\mathrm{CrO}_{3} / 4 \mathrm{M} \mathrm{H}_{2} \mathrm{SO}_{4}$ solution at $50^{\circ} \mathrm{C}$ for $30 \mathrm{~min}$. The maximum value of the conductivity of the test samples was $6 \mathrm{nS} / \square$ at $0.004 \mathrm{M} \mathrm{NaBH}_{4}$, and the surface appeared to be bright metallic copper.

(Received February 8, 1996 ; Accepted February 20, 1996)

\section{References}

1) T. Arai, H. Oda and T. Katayose ; Electronic Circuit \& Packaging Technology, 9, 429 (1994)

2) C. J. Pouchert ; The Aldrich Library of FT-IR Spectra, 2, 1209 (1985)

3) C. J. Pouchert ; The Aldrich Library of FT-IR Spectra, 1, 813 (1985)

4) H. Nawafune, K. Kugo, S. Mizumoto, M. Seita and M. Imanari ; Hyomen Gijutsu, 46, 579 (1995) 